\title{
THE EFFECTS OF PUBLIC R\&D SUBSIDIZED LOANS ON FIRMS' R\&D OUTPUTS: EVIDENCE FROM CHINA
}

\author{
Yuchen $\mathrm{GAO}^{1}$, Si ZHANG ${ }^{*}$, Yimei $\mathrm{HU}^{3}$ \\ ${ }^{1}$ School of Public Policy and Management, Tsinghua University, Beijing, China \\ ${ }^{2}$ School of Economics and Management, University of Chinese Academy of Sciences, Beijing, China \\ ${ }^{3}$ AAU Business School, Aalborg University, Aalborg, Denmark
}

Received 24 March 2020; accepted 29 January 2021

\begin{abstract}
R\&D subsidized loans (tiexi daikuan) is an effective market-driven solution to promote firms' R\&D outputs, including patent applications and new product sales, in China. However, empirical examination on the effects of subsidized loans is insufficient. Using a panel data of manufacturing firms of Jiangsu Province from 2010 to 2014, the study investigates the effects of R\&D subsidized loans on firms' $R \& D$ outputs in comparison to that of the direct $R \& D$ grants. The results show that $R \& D$ subsidized loan recipients significantly outperform those who only receive direct grants in terms of new product sales. Meanwhile, subsidized loans inhibit the recipients' exploratory patent applications and discourage R\&D activities with higher risks. This study contributes to R\&D subsidy literature and extends the knowledge in the roles of different types of public sponsorships on firms' innovation.
\end{abstract}

Keywords: R\&D subsidy, subsidized loans, R\&D outputs, China, innovation policy, exploratory patents.

JEL Classification: H25, H81, L60, M21, O3.

Online supplementary material: Supporting information for this paper is available as online supplementary material at https://doi.org/10.3846/jbem.2021.14581

\section{Introduction}

Firms' R\&D activities are often trapped in market failure. For this reason, public intervention from the government becomes necessary (Arrow, 1962; Nelson, 1959). Public R\&D subsidy is one of the most prevalent policy instruments that help with overcoming R\&D related market failure and spurring firm's R\&D activities (David et al., 2000; Dimos \& Pugh, 2016). The effects of R\&D subsidies on the R\&D input and output of firms are profoundly discussed in the existing literature (Dimos \& Pugh, 2016; Zuniga-Vicente et al., 2014). Although several

\footnotetext{
*Corresponding author. E-mail: zhangsi@ucas.ac.cn
} 
studies demonstrate the existence of an additionality effect on firms' R\&D input such as private $R \& D$ expenditure, whether $R \& D$ subsidies can promote firms' $R \& D$ outputs remains ambiguous (Dimos \& Pugh, 2016). This can be a result of the ambiguity in the heterogeneities of different types of R\&D subsidies overlooked by most extant studies.

The majority of $\mathrm{R} \& \mathrm{D}$ subsidies are provided through direct $\mathrm{R} \& \mathrm{D}$ grants (Hottenrott \& Richstein, 2020; Xin et al., 2016). Direct R\&D grant with no interest and repayment pressure, which can directly compensate resource shortage in private sectors, is the most prevailing $\mathrm{R} \& \mathrm{D}$ subsidy amongst the usual types, especially in transitional economies where the capital markets are under-developed (Zheng et al., 2015). However, direct R\&D grants, as an administrative ex-ante subsidy, are considered to stimulate productive insufficiency of R\&D activities due to the misalignment of interests and information asymmetry between governments and subsidy recipients (Jourdan \& Kivleniece, 2017; Perez-Sebastian, 2015). This issue is exacerbated in transitional economies because of the stronger public intervention (Tang et al., 2019; Wang et al., 2017).

To overcome the potential flaws of direct R\&D grants, another primary form of subsidy, $\mathrm{R} \& \mathrm{D}$ subsidized or interest-reduced loans, is designed. R\&D subsidized loans, also called tiexi daikuan, are widely adopted by the Chinese government in strategic emerging industries to support the R\&D activities of firms (Grau et al., 2012; Jiang et al., 2012; Liang, 2014). This evolved subsidy scheme is essentially a business loan, in which the government pays back a proportion or all the interests to commercial banks on behalf of the subsidy recipients (Grau et al., 2012). Through R\&D subsidized loans, the government provides endorsement for firms and reduces the cost of financing of the banks (Hottenrott \& Richstein, 2020). In recent years, R\&D subsidized loans have attracted growing attentions from both academics and policymakers (Bertoni et al., 2019; Hottenrott \& Richstein, 2020; Huergo \& Moreno, 2017; Zhao \& Ziedonis, 2020).

Chinese firms are endowed a crucial role in the fulfillment of the national strategy, such as the "Indigenous Innovation Initiative" ${ }^{1}$, and are expected to contribute to the economic transformation and industrial upgrading. To elevate firms' innovation abilities and to transform the innovation outputs into market competitiveness, the Chinese government has launched a series of R\&D subsidy programs for firms in compliance with the national indigenous innovation strategy (Guo et al., 2016; Huang et al., 2016; Wang et al., 2017). R\&D subsidies in China amounted to 398 billion RMB in 2018, accounting for around 20.22\% of the total national R\&D expenditure ${ }^{2}$. Among the R\&D subsidies, direct grants and subsidized loans are the two main types. Extant studies have indicated that R\&D subsidies from the Chinese government can stimulate firms' own R\&D expenditure (Liu et al., 2016), in terms of which R\&D subsidized loans have higher efficiency (Xin et al., 2016). However, the research on the effects of different types R\&D subsidies on Chinese firms' R\&D outputs, e.g., patent applications and new product sales, is still insufficient. An exception is Guan and Yam (2015), which discerns the influence of different $\mathrm{R} \& \mathrm{D}$ subsidy programs on patent applications and new product sales of firms in China, but they set the scene of their research in the 1990s of China, when the first factor-driven transformation was ongoing. Since the $21^{\text {st }}$ Century, China has entered the innovation-driven transformation period. Could the effect of subsidized loans on $\mathrm{R} \& \mathrm{D}$ outputs, including patent applications and new product sales, have changed? Compared 
with direct R\&D subsidy, how different is tiexi daikuan's role in firms' R\&D outputs? These questions are yet to be probed. In recent years, instead of merely pursuing for more patent applications, the Chinese government expects to promote technological innovation and industrial upgrading by encouraging firms to explore and adopt unfamiliar knowledge in their R\&D activities, i.e., exploratory activities. However, firms' patent applications based on novel knowledge which are entirely new to firms are often more risky and uncertain. Whether R\&D subsidies can trigger exploratory R\&D activities are also largely unknown.

To fill the gaps, the study attempts to empirically examine the effects of R\&D subsidized loan on R\&D outputs of firms, including patent applications and new product sales, in comparison to the effects of direct grants in China. Regarding patent applications, the study focuses on firms' exploratory patent application containing novel knowledge that firms are not familiar with. Based on a panel data of manufacturing firms from Jiangsu Province, China, it is found that, compared to direct grants, R\&D subsidized loans significantly exert more positive effects on firms' new product sales, while providing less motivation for firms to undertake exploratory patent applications. The results of the study extend the knowledge of R\&D subsidies by distinguishing the effects of different types of public subsidy tools. In addition, this study supplements the research on governmental funds to firms' R\&D outputs in transition economies. Finally, empirical evidence is further provided for literature on R\&D subsidized loans. Several important policy implications based on the results are also suggested.

The rest of this paper is structured as follows: Section 1 lays out the literature review and hypotheses development. Section 2 describes the data, research context, variables, and employed econometric methods. Section 3 presents the empirical results. The discussion based on the empirical results will be deposited in Section 4. The final section presents the concluding remarks, implications, and future research directions.

\section{Literature review and hypotheses development}

$\mathrm{R} \& \mathrm{D}$ activities are associated with relatively higher costs and risks. Due to the attributes of public goods and the imperfections of the capital market, firms' R\&D activities are often constrained by resources (David et al., 2000; Zuniga-Vicente et al., 2014). Resource constraints may impede firms' innovation intentions and R\&D investment, which further hinders their capabilities to produce R\&D outputs, e.g., patents and new products (Dimos \& Pugh, 2016; Hottenrott \& Richstein, 2020).

R\&D subsidies, according to the resource-based view, directly increase the pool of available resources for firms' R\&D activities by overcoming resource deficiency (David et al., 2000). R\&D subsidies may further trigger the so-called additionality effects that alter firms' innovation behaviors. For instance, the additionality effect can be the increase of private R\&D investment, which thereby the elevating of firms' technological capabilities (Hottenrott \& Richstein, 2020; Wernerfelt, 1984). Higher technological capabilities can in turn assist firms to better allocate resources to facilitate innovation performances (Verona, 1999).

With the additional resources, firms are also encouraged to undertake more challenging R\&D activities due to their elevated risk tolerance (Chapman \& Hewitt-Dundas, 2018). Ac- 
cording to the Pecking Order Theory, the direct subsidy will urge firms to pick the projects with the highest expected returns. Yet the projects with high expected returns are often associate with high-risk and technological novelty (Hottenrott \& Richstein, 2020). As directly subsidized firms that implement R\&D projects only consider the differences between the benefit and the cost as their expected return. If a firm does not receive public sponsorship, the costs of its R\&D projects must be withstood solely by the firms should the projects fail. This will lower firms' intentions to undertake more challenging R\&D projects with higher risk. As R\&D subsidies directly improve the internal capital pool of the recipient firms, even if the firms face higher probability of failure led by increased risks, the actual loss is (partially) covered by the R\&D subsidies. Thus, R\&D subsidies can increase recipient firms' risk tolerance (Chapman \& Hewitt-Dundas, 2018). This motivating incentive is especially important for firms' exploratory R\&D activities through searching and adopting novel knowledge, and also exhibits reward for the long-term success of innovation (Manso, 2011).

At the same time, R\&D subsidies also buffer the firms from environmental threats and uncertainties by providing critical resources with no associated prices or value-related claims (Jourdan \& Kivleniece, 2017; Zhou et al., 2020). More specifically, firms must cope with the fast changing markets with high uncertainties which may restrain firms from allocating resources in $\mathrm{R} \& \mathrm{D}$ projects with higher novelty, due to the risk-averse nature and financial constraints of firms (Beck et al., 2016; Bronzini \& Piselli, 2016; Zhou et al., 2020). R\&D subsidies can hereby create a resource munificent environment for firms, protecting them from the unfavorable uncertainties and risk (Jourdan \& Kivleniece, 2017). By accepting R\&D subsidies, recipient firms can be protected from potential adverse selection, whereby technological capabilities and resource are enhanced and allocated more effectively to high-risk but innovative explorations (Rangan et al., 2006). Thus, R\&D subsidies can encourage firms to undertake exploratory R\&D activities that generate novel knowledge, trigger more exploratory patent applications, and provide new products under adverse market conditions (Zhou et al., 2020). The following hypotheses are hereby proposed:

Hypothesis 1a: Receiving R\&D subsidies increases firms' exploratory patent applications.

Hypothesis 1b: Receiving R\&D subsidies increases firms' new product sales.

However, if R\&D subsidies are only provided through direct grants, negative effects on firms' R\&D outputs can show. As an administrative ex-ante subsidy, direct R\&D grants may miss the intended goal to encourage innovation output due to the misalignments of interest and information asymmetries (Guan \& Yam, 2015; Hall \& Van Reenen, 2000; Jourdan \& Kivleniece, 2017). More specifically, firms in nature are profit seekers while governments concern more about the social welfare. Governmental officials in China are more concerned about the implementation of national strategies set by the central government which may not necessarily match the market-driven targets of firms (Li et al., 2018). Although conducting R\&D activities with higher risks may enhance firms' innovation capabilities and generate novel technological outputs, sponsored firms are less motivated to do so (Tang et al., 2019). Furthermore, due to the information asymmetry between firms and the government, sponsored firms often lack internal disciplines (Jourdan \& Kivleniece, 2017). Meanwhile, governmental agencies lacking of value-based governance often fail to provide sufficient incentives for firms to undertake risky R\&D activities (Dixit, 1997; Zhou et al., 2020). Thus, sponsored firms tend 
to allocate resources to projects that are low-risk and high-yielding but less innovative, or in nonproductive rent-seeking activities to obtain continuous government supports (Antonelli \& Crespi, 2013). This matter is exacerbated by the lack of a supervision mechanism, which comes from the fact that firms access direct subsidies through non-market exchange mechanism (Jourdan \& Kivleniece, 2017).

Subsidized loans (tiexi daikuan) are designed to correct the aforementioned insufficiency of direct R\&D grants. First of all, R\&D subsidies are obtained through competition (Xin et al., 2016). In China, firms which intended to apply for or has already gained bank loans for R\&D projects are qualified for government subsidized loans. It is a convention that the government pays back the interests on firms' behalf at the due date of the loan should its debtors fail. The government does not guarantee the approval of loans or interfere with banks' lending decision process. This implies that firms should compete to win the subsidized loans (Xin et al., 2016). Thus, under market principles, subsidized loan receivers will have stronger willingness to undertake high-risk R\&D projects that possess higher potential in technological outputs (Xin et al., 2016). Secondly, through subsidized loans, banks and the government share the risks associated with R\&D activities. The recipients of loans will be subject to more strict supervision in the use of funds, which eases the information asymmetry between fund recipients and providers. Thirdly, the subsidy of subsidized loans improves the internal discipline of the funds used by firms in R\&D activities (Huergo \& Moreno, 2017; Huergo \& Trenado, 2010; Huergo et al., 2016). Compared with direct R\&D subsidies that has little cost, the subsidized loans require the firms to repay the principal at the end of the project. The only way to gain public R\&D subsidized loans is to do their bests to secure the success of sponsored $\mathrm{R} \& \mathrm{D}$ activities. This means that loan receivers need to take the initiatives to invest in R\&D activities before the government money flows in. As demonstrated by Xin et al. (2016), the promoting effect of subsidized loan is better than that of direct subsidy on the R\&D investment of enterprises. Due to the pressure of loan repayment and the pursuit of government pledged interest rate, recipient firms manage to limit the waste of funds and exert better innovation performance. In this way, the government is able to prevent firms rent-seeking behaviors and enhance the efficiency of firm's resource utilization during the $\mathrm{R} \& \mathrm{D}$ processes. Therefore, the hypothesis is proposed as:

Hypothesis 2a: Compared with those only receiving direct R\&D grants, firms that also receive R\&D subsidized loans file more exploratory patent applications.

From the perspective of cost-expected return, it is suggested that subsidized loans have a better promoting effect on the commercial outputs of R\&D, such as improved performance of tangible asset investment and new product output (Hottenrott \& Richstein, 2020). Compared with direct R\&D grant, subsidized loan must consider the repayment obligation. The expected return of the firms should subtract the repayment obligation from the difference between the benefit and the cost. Should the project fail, firms need to bear the relevant costs occurred plus the repayment obligation. That is to say, subsidized loan recipients have to dedicate some skin in the game. Therefore, on the one hand, loan receivers will choose the projects with lower risk to ensure the expected return. While on the other hand, recipient firms are more willing to invest on the follow-up product development and commercialization, to transform the technological advancements and R\&D achievements into tangible assets and market rev- 
enue. There are two reasons behind this. First, the risk of product development based on technological innovation results is lower. Second, by investing in tangible assets, even if the project fails, those assets can still be used as a deduction to debt. In other words, compared to the situation that once the technology $\mathrm{R} \& \mathrm{D}$ projects fail and all investments sink, subsidized loans reduce the overall potential losses. In addition, subsidized loans are fully compatible with tax benefits which direct subsidy misses (Huergo et al., 2016). Subsidized loans also promotes the recipients to pursue the economic benefits based on research and development, so as to enjoy the reduction of costs of new product sales and the improvement of returns brought by subsidized loans and tax incentives. Therefore, the hypothesis is proposed as:

Hypothesis 2b: Compared with those only receiving direct R\&D grants, firms that also receive $R \& D$ subsidized loans generate more new product sales.

\section{Data and methods}

\subsection{Data and research context}

This research focuses on $\mathrm{R} \& \mathrm{D}$ subsidy recipient firms in the manufacturing sectors in Jiangsu province, China. Jiangsu province is one of the coastal regions and leading innovative areas in China. In 2018, the revenue of the high-tech industries in Jiangsu was 2616 billion $\mathrm{RMB}^{2}$. In the same year, the total R\&D expenditure in Jiangsu was 250.4 billion RMB with an R\&D intensity of $2.70 \%$. Among the total R\&D expenditure, 218.2 billion RMB came from enterprises, while government funds accounted for 25.4 billion $\mathrm{RMB}^{2}$. Seven national-level and thirteen provincial-level innovation incentive programs comprised by various types of $\mathrm{R} \& \mathrm{D}$ subsidies can be accessed by firms from Jiangsu Province ${ }^{3}$.

The effect of public R\&D subsidy is influenced by the scientific, technological and economic environment (David et al., 2000). Differences in subsidy effect also exist across manufacturing and other industries (e.g., service sectors). Thus, a province-level study of manufacturing industry alone can reduce the potential unobservable influences irrespective of any regional disparity in terms of economic, policy and culture heterogeneity of dispersed Chinese provinces (Dimos \& Pugh, 2016). Specifically, an exclusive panel data is employed from a survey conducted by the Jiangsu Government, covering the period from 2010 to $2014^{4}$. The purpose of the survey was to evaluate the effects of R\&D subsidy and innovation performances of enterprises in Jiangsu Province.

The provincial level Innovation Fund for Technology-Based Small and Medium-Size Enterprises (SMEs) is selected as the R\&D subsidy program to be investigated in this study. According to the Handbook of Policies towards Firm's Technological Innovation, the innovation fund is a non-for-profit public R\&D subsidy program, which aims to enhance Chinese technology-based SMEs' technological capabilities in research and promote their market competitiveness with new product development. Jiangsu officially launched its own technology innovation fund program for technology-based SMEs in $2007^{5}$. In principle, this provincial fund provides direct R\&D grants, around 0.3 to 0.5 million CNY to each selected project. Firms' applying for this provincial innovation program should fulfill the following criteria $^{3}$. The applying firms' innovation projects should satisfy the national and provincial 
industrial technology policies, and show considerable level of novelty, strong market competitiveness and economic potential, and potential social welfare improvement. In particular, applicants should belong to industries with strategic priority and importance for Jiangsu's development. In principle, the program is in favor of high-tech SMEs whose annual R\&D expenditure is no less than 3\% of the annual sales. The selected SMEs should have no more than 500 employees, of which at least $30 \%$ own college degrees or the above. At the same time, Jiangsu also launched another support plan in 2006, providing subsidized loans to technology-based SMEs to encourage and promote their innovation activities ${ }^{6}$. The main target of the program of subsidized loans is to encourage external financial institutions to support technological innovation of SMEs. The firms applying for subsidized loans should satisfy the industrial technology policies with promising technological and market potentials. The applicants should also be technology-based SMEs engaged in the research, development and application of new technologies. Thus, the subsidized loans program have similar selection criteria to the innovation fund for SMEs. A firm from Jiangsu Province can receive both types of subsidy simultaneously.

The survey includes both subsidy recipients and non-subsidy recipients, which fits the research objective. The initial dataset has 1273 firms with 6362 firm-year observations. Furthermore, the survey dataset is supplemented with firms' patent data obtained from the State Intellectual Property Office (SIPO). During the observation period, 142 firms in this dataset received $R \& D$ subsidies, among which 41 have obtained both direct grants from the innovation fund and subsidized loans, and 101 firms only received direct grants.

\subsection{Variables}

The dependent variable of this study is innovation outputs, including exploratory patent applications and new product sales. Informed by existing literature, the lagged value of the ratio of new product sales revenue (New_Product) and that of novel patent applications for one year (Patent) each are employed (Griliches, 1990; Guan \& Yam, 2015; Jia et al., 2019). The "novel knowledge" of a firm is defined according to Ahuja and Lampert (2001). Based on the patent history of a firm, if certain IPC codes that have not appeared in the past four years appear in the technology combination of a patent applied by the firm in a specific year, the patent can be defined as an application with novel knowledge (Ahuja \& Lampert, 2001). As novel knowledge is new to firms, the ratio of novel patent applications indicates the willingness of firms to undertake high-risk exploratory R\&D and the potential to produce subsequent technological output with higher value (Jia et al., 2019).

For the independent variable, a dummy variable is used to denote the receiving of public $\mathrm{R} \& \mathrm{D}$ subsidies from the provincial innovation fund (Subsidy). Subsidy is set to 1 from and including the year when the firm receives a subsidy, and 0 if received before that year or never receive subsidies in the observation period. To test the heterogeneous effects of subsidized loans, this study also sets the dummy variable Sub_loans. Specifically, if a firm received subsidized loans in the observation period, Sub_loans valued 1, otherwise 0 . Informed by exiting literature, a series of control variables are also considered in the study. Table 1 concludes the independent, dependent, and control variables. 
This study also sets industry dummies (Industry_Dummy) based on the 2-digit industrial codes; regional dummies (Region_Dummy) based on south, north, and central areas of Jiangsu; year dummies (Year_Dummy) to account for differences in the macroeconomic environments over the years.

Table 1. The variables list

\begin{tabular}{|c|c|c|}
\hline Definition & Variable & Measure \\
\hline \multirow{2}{*}{ R\&D Outputs } & $\begin{array}{l}\text { New }_{-} \\
\text {Product }\end{array}$ & $\begin{array}{l}\text { The ratio of new product sales revenue of the focal firm with } \\
\text { one year lagged. }\end{array}$ \\
\hline & Patent & $\begin{array}{l}\text { The ratio of patent applications with novel knowledge of the } \\
\text { focal firm with one year lagged. }\end{array}$ \\
\hline R\&D Subsidy & Subsidy & $\begin{array}{l}\text { Subsidy is set to } 1 \text { from and including the year when the firm } \\
\text { receives a subsidy, and set to } 0 \text { before that year. }\end{array}$ \\
\hline Subsidized Loans & Sub_loans & $\begin{array}{l}\text { If a firm has received subsidized loans in the observation period, } \\
\text { Sub_loans valued } 1 \text {, otherwise } 0 \text {. }\end{array}$ \\
\hline $\begin{array}{l}\text { Technological } \\
\text { Diversity }\end{array}$ & Tech_diver & $\begin{array}{l}\text { Tech_diver }{ }_{i t}=\sum_{j=1}^{N} P_{j} \times \ln \left(1 / P_{j}\right) \\
P_{j} \text { is the proportion of the number of invention patents with } \\
\text { certain four-digit IPC code applied for in the three years prior } \\
\text { Year t to the total number of invention patents applied for by a } \\
\text { firm i during the same period (Teachman, 1980). }\end{array}$ \\
\hline $\begin{array}{l}\text { Technological } \\
\text { Capability }\end{array}$ & Tech_capa & $\begin{array}{l}\text { The ratio of intangible assets to total assets (Hall, 1992). } \\
\text { Intangible assets refer to the value of various intangible } \\
\text { resources used and developed by firms themselves or purchased } \\
\text { from the outside sources of their R\&D activities. }\end{array}$ \\
\hline $\begin{array}{l}\text { The Prior Expe- } \\
\text { rience Of R\&D } \\
\text { Subsidies }\end{array}$ & Pre_subsidy & $\begin{array}{l}\text { If a firm received R\&D subsidies during the three years before } \\
2010 \text {, the dummy is } 1 \text {, otherwise } 0 \text { (Clarysse et al., 2009). }\end{array}$ \\
\hline $\begin{array}{l}\text { The High-Educa- } \\
\text { tional Employee } \\
\text { Ratio }\end{array}$ & Hi_edu & $\begin{array}{l}\text { the proportion of employees with a bachelor's degree or above } \\
\text { in the total number of employees. }\end{array}$ \\
\hline $\begin{array}{l}\text { Firm-Level Patent } \\
\text { Stock }\end{array}$ & Pat_stock & $\begin{array}{l}\text { Pat_stock }{ }_{t}=\text { Patent }_{t}+(1-\delta) \times \text { Pat_stock } \\
\text { The Patent } \\
\text { ti is the number of invention patents obtained by the } \\
\text { firm in year t. } \delta \text { is a constant depreciation rate of } 15 \% \text { (Lach, } \\
\text { 1995). The patent stock is divided by the number of employees } \\
\text { of each firm. }\end{array}$ \\
\hline R\&D Intensity & RD_int & the ratio of R\&D expenditure on firms' total sales at year $t$. \\
\hline Capital Intensity & Cap_int & $\begin{array}{l}\text { The natural logarithm of net fixed assets divided by the number } \\
\text { of employees (Boeing, 2016). }\end{array}$ \\
\hline Firm Size & Firm_Size & The natural logarithm of the number of employees. \\
\hline Firm Age & Firm_Age & $\begin{array}{l}\text { The natural logarithm of the number of years since the firm is } \\
\text { founded. }\end{array}$ \\
\hline $\begin{array}{l}\text { Firm R\&D } \\
\text { Institutions }\end{array}$ & RD_Dpart & $\begin{array}{l}\text { Whether a firms is equipped with R\&D institutions, such as } \\
\text { testing base, R\&D center, and laboratories (Hussinger, 2008). }\end{array}$ \\
\hline $\begin{array}{l}\text { High-Tech Manu- } \\
\text { facture Sectors }\end{array}$ & Hi_Tech & Whether a firms is engaged in high-tech manufacturing sectors. \\
\hline
\end{tabular}




\subsection{Methods}

To reduce the selection bias, propensity score matching (PSM) is conducted before testing the hypotheses. PSM is run at the baseline period of firms, i.e., the first year R\&D subsidy programs initiated, to ensure that the initial conditions between $R \& D$ subsidy recipient and non-recipient firms have no systematic bias when entering the observation period. For the matching, the firms that participate in the Innovation Fund for SMEs as the treatment group and those non-participants are used as the control group. It is necessary to notice here, $R \& D$ subsidized loans recipients are among those firms which receive the innovation fund. A set of covariates is selected according to the screening criteria of the innovation fund (see Table A.1 in the Appendix). Furthermore, based on the covariates, a significance t-test is provided between the firms receiving the innovation fund only and the firms also receiving subsidized loans. It is necessary to reject the bias between the two groups, as different types of support may appeal to different types of firms. According to Table A.2, no significant systematic differences exist between these two groups of sponsored firms.

The Probit estimation is further adopted based on the base period to estimate the propensity scores. Table A.3 presents the results (Model A1). 1-1 nearest neighborhood matching (1-1 NNM) without replacement is performed to identify the control group of firms. Meanwhile, a caliper with a pre-specified tolerance at 0.025 is used to avoid the "bad" matches. Two firms receiving subsidies are dropped during the PSM process as they cannot satisfy the common support condition. Based on the PSM sample, the propensity scores are re-estimated with the result of which is presented in Table A.3 (Model A2). As shown in Table A.3, no single covariate remains significance, and the pseudo-R square drops sharply from 0.100 to 0.007 after matching on the base period, suggesting that the systematic differences in the distribution of covariates between the treatment and the control groups have been removed from the PSM sample.

A balance test is also provided for the means of covariates between the treatment and control groups (see Table A.4). According to the $t$-test and the corresponding $p$ value on mean differences for covariates, the means of covariates are balanced between the treatment and control groups. In addition, the mean standardized bias (MSB) drops sharply after the matching, which suggests a successful matching. Based on the PSM results of the baseline period, the corresponding subsequent data in the following period are supplemented. The final PSM sampling comprises 280 firms with 1398 firm-year observations. The industrial distribution of these firms (based on the 2-digital industrial code) and regional distributions can be found in Table A.5 and A.6 in the Appendix.

In the PSM samples, over $48.7 \%$ observations have the value 0 for Patent while $18.1 \%$ have the value 1 , and $13.2 \%$ observations have the value 0 for New_Product while 5.6\% have the value 1 . Thus, double-censored Tobit models with random effects are performed for the empirical analyses (Jia et al., 2019; Li et al., 2018). As a censored regression model, the Tobit model provides consistent estimators for the model parameters when the dependent variables are censored. 


\begin{tabular}{|c|c|c|c|c|c|c|c|c|c|c|c|c|c|c|c|c|c|c|}
\hline$\stackrel{2}{\sim}$ & & & & & & & & & & & & & & & $\begin{array}{l}8 \\
\\
\\
\end{array}$ & $\begin{array}{l}\infty \\
\stackrel{\infty}{-} \\
-1\end{array}$ & సิ & $\underset{\stackrel{\overbrace{}}{\sharp}}{\stackrel{\circ}{0}}$ \\
\hline$\Xi$ & & & & & & & & & & & & & & 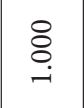 & 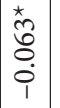 & 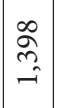 & ลิ & 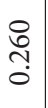 \\
\hline 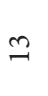 & & & & & & & & & & & & & $\underset{-}{\stackrel{8}{\circ}}$ & $\begin{array}{l}\text { to } \\
\stackrel{0}{0} \\
\stackrel{0}{0} \\
0\end{array}$ & $\begin{array}{l}0 \\
0 \\
0 \\
0 \\
1 \\
1\end{array}$ & $\begin{array}{l}\infty \\
\stackrel{\infty}{2} \\
\stackrel{-}{-1}\end{array}$ & $\frac{n}{\sim}$ & $\begin{array}{l}+ \\
\stackrel{0}{0} \\
\stackrel{0}{0}\end{array}$ \\
\hline$\underset{I}{\sim}$ & & & & & & & & & & & & $\stackrel{8}{\stackrel{8}{\circ}}$ & 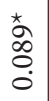 & $\begin{array}{l}\star \\
\stackrel{\star}{0} \\
0 \\
0 \\
0\end{array}$ & $\begin{array}{l}\infty \\
0 \\
0 \\
0 \\
1 \\
1\end{array}$ & $\begin{array}{l}\infty \\
\stackrel{\infty}{\sim} \\
-1\end{array}$ & $\underset{\stackrel{L}{0}}{\underset{\sim}{*}}$ & $\begin{array}{l}\hat{n} \\
\hat{n} \\
0 \\
0\end{array}$ \\
\hline$\exists$ & & & & & & & & & & & 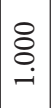 & \begin{tabular}{l}
\multirow{2}{\infty}{} \\
0 \\
$\hat{0}$ \\
0 \\
1 \\
1
\end{tabular} & $\begin{array}{l}\star \\
\infty \\
\infty \\
\infty \\
\infty \\
0 \\
1 \\
1\end{array}$ & $\begin{array}{l}\vec{F} \\
\dot{0} \\
\dot{0}\end{array}$ & $\begin{array}{c}\hat{n} \\
0 \\
0\end{array}$ & 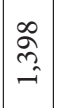 & $\begin{array}{l}1 \\
0 \\
0 \\
0\end{array}$ & $\begin{array}{l}0 \\
0 \\
0 \\
0 \\
0\end{array}$ \\
\hline$\stackrel{\circ}{-}$ & & & & & & & & & & $\begin{array}{l}8 \\
\\
\\
\end{array}$ & 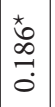 & $\begin{array}{l}\vec{n} \\
0 \\
\dot{0} \\
1\end{array}$ & 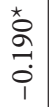 & $\begin{array}{l}\text { 离 } \\
0 \\
0 \\
\dot{1}\end{array}$ & 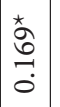 & $\begin{array}{l}\infty \\
\stackrel{\infty}{\sim} \\
-1\end{array}$ & 종 & $\begin{array}{l}2 \\
\text { oे } \\
0\end{array}$ \\
\hline$a$ & & & & & & & & & $\underset{8}{8}$ & 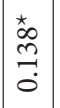 & \begin{tabular}{|l|}
\multirow{2}{*}{} \\
$\hat{\delta}$ \\
$\tilde{n}$ \\
0 \\
\end{tabular} & $\begin{array}{l}\tilde{\delta} \\
\tilde{0} \\
\dot{0}\end{array}$ & 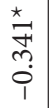 & $\overrightarrow{8}$ & 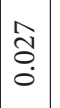 & $\mid \begin{array}{l}\infty \\
2 \\
2 \\
-\sim\end{array}$ & $\begin{array}{l}0 \\
0 \\
0 \\
0\end{array}$ & $\begin{array}{l}0 \\
\stackrel{0}{0} \\
0\end{array}$ \\
\hline$\infty$ & & & & & & & & \begin{tabular}{l}
8 \\
\hdashline \\
\\
\end{tabular} & 离 & 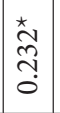 & 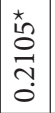 & $\begin{array}{l}\text { Pi! } \\
0 \\
\dot{0} \\
1\end{array}$ & 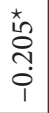 & $\begin{array}{l}\star \\
\infty \\
\infty \\
0 \\
0 \\
0 \\
1\end{array}$ & 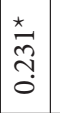 & $\begin{array}{l}\infty \\
\stackrel{2}{2} \\
\stackrel{-}{-}\end{array}$ & m. & $\underset{\text { ㄱ. }}{\stackrel{0}{0}}$ \\
\hline$\wedge$ & & & & & & & ஓి & $\begin{array}{l}\tilde{L} \\
\tilde{\delta} \\
0 \\
0\end{array}$ & 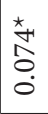 & $\begin{array}{l}-1 \\
0 \\
0 \\
0\end{array}$ & \begin{tabular}{|l|}
\multirow{2}{*}{} \\
$\hat{N}$ \\
$\tilde{O}$ \\
0 \\
0
\end{tabular} & $\begin{array}{l}\stackrel{\star}{N} \\
\stackrel{\hat{O}}{0} \\
\stackrel{0}{0}\end{array}$ & \begin{tabular}{|l|} 
\\
$\hat{\sigma}$ \\
0 \\
0 \\
0 \\
1 \\
\end{tabular} & $\begin{array}{l}+ \\
\stackrel{0}{0} \\
\stackrel{0}{0}\end{array}$ & \begin{tabular}{|l|} 
\\
$\hat{L}$ \\
$\hat{L}$ \\
0 \\
0 \\
0
\end{tabular} & $\begin{array}{l}\infty \\
\stackrel{2}{m} \\
\\
-1\end{array}$ & 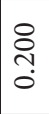 & $\begin{array}{l}8 \\
\stackrel{+}{+} \\
0\end{array}$ \\
\hline 6 & & & & & & $\stackrel{8}{\stackrel{一}{-}}$ & 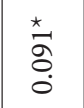 & $\begin{array}{l}\text { t } \\
0 \\
0 \\
0 \\
0\end{array}$ & $\begin{array}{l}\mathscr{2} \\
0 \\
0 \\
1\end{array}$ & \begin{tabular}{|l|}
\multirow{2}{*}{} \\
$\stackrel{2}{2}$ \\
$\vdots$ \\
0
\end{tabular} & $\overrightarrow{0}$ & $\begin{array}{l}\hat{\tilde{\theta}} \\
\dot{0}\end{array}$ & \begin{tabular}{|l|} 
\\
\multirow{2}{*}{} \\
0 \\
0 \\
1 \\
1
\end{tabular} & $\begin{array}{l}\stackrel{0}{0} \\
\dot{0} \\
\dot{0}\end{array}$ & 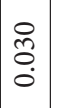 & $\begin{array}{l}\infty \\
\stackrel{2}{\sim} \\
-1 \\
\end{array}$ & 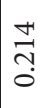 & ڤે \\
\hline in & & & & & 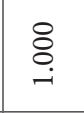 & $\begin{array}{c}\vec{\sigma} \\
0 \\
0\end{array}$ & \begin{tabular}{l}
\multirow{1}{\infty}{} \\
$\stackrel{\infty}{m}$ \\
$\stackrel{-}{0}$
\end{tabular} & $\begin{array}{l}\stackrel{\star}{i n} \\
= \\
0 \\
\end{array}$ & 齐 & $\begin{array}{l}\infty \\
0 \\
0 \\
0\end{array}$ & 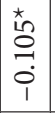 & 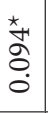 & $\begin{array}{l}\star \\
\stackrel{m}{ } \\
\stackrel{0}{0}\end{array}$ & ભે & 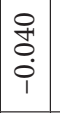 & $\stackrel{\infty}{\stackrel{2}{\sim}}$ & $\begin{array}{l}\text { Tै } \\
\infty \\
0 \\
0\end{array}$ & $\stackrel{m}{\stackrel{n}{0}}$ \\
\hline 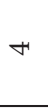 & & & & هִ & $\begin{array}{l}\text { th } \\
\stackrel{0}{0} \\
0 \\
0 \\
0\end{array}$ & $\begin{array}{l}\infty \\
\stackrel{8}{0} \\
0\end{array}$ & $\begin{array}{l}+ \\
\\
0 \\
1\end{array}$ & $\begin{array}{l}\frac{\star}{\sigma} \\
\frac{\sigma}{0} \\
0\end{array}$ & $\begin{array}{l}\text { * } \\
\vdots \\
0 \\
\vdots \\
0\end{array}$ & \begin{tabular}{|l|}
\multirow{2}{*}{} \\
$\hat{n}$ \\
0 \\
0 \\
0 \\
\end{tabular} & \begin{tabular}{|l|}
0 \\
$\tilde{\delta}$ \\
0 \\
0 \\
1 \\
\end{tabular} & $\begin{array}{l}\stackrel{\partial}{0} \\
0 \\
0 \\
i\end{array}$ & \begin{tabular}{l}
\multirow{2}{*}{} \\
$\hat{\sigma}$ \\
$\hat{o}$ \\
0 \\
0
\end{tabular} & $\begin{array}{l}0 \\
0 \\
0 \\
\dot{0}\end{array}$ & 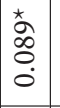 & $\begin{array}{l}\infty \\
\stackrel{\infty}{2} \\
-1\end{array}$ & $\stackrel{n}{\stackrel{2}{0}}$ & $\begin{array}{l}\stackrel{0}{0} \\
\text { ma } \\
0\end{array}$ \\
\hline$m$ & & & $\underset{-}{8}$ & 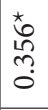 & $\begin{array}{l}\stackrel{\star}{m} \\
\stackrel{0}{0} \\
0\end{array}$ & $\begin{array}{l}\stackrel{9}{0} \\
\text { ठ }\end{array}$ & $\begin{array}{l}\overrightarrow{8} \\
\dot{0} \\
\dot{1}\end{array}$ & 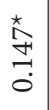 & $\begin{array}{l}\star \\
0 \\
0 \\
0 \\
0 \\
0\end{array}$ & $\mid$\begin{tabular}{l|}
\multirow{1}{*}{} \\
$\hat{L}$ \\
0 \\
0 \\
0 \\
0
\end{tabular} & $\begin{array}{l}\infty \\
\tilde{D} \\
\dot{0} \\
\dot{0}\end{array}$ & 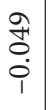 & $\begin{array}{c}\infty \\
\tilde{m} \\
0 \\
0 \\
1 \\
1\end{array}$ & 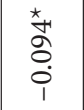 & 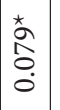 & $\stackrel{\infty}{\stackrel{2}{\sim}}$ & 울 & $\begin{array}{l}\stackrel{+}{+} \\
\stackrel{+}{0}\end{array}$ \\
\hline$\sim$ & & $\underset{ن}{8}$ & 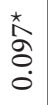 & 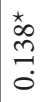 & 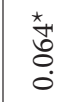 & $\begin{array}{l}\overrightarrow{\widetilde{O}} \\
\stackrel{0}{0}\end{array}$ & $\begin{array}{l}\hat{\delta} \\
\stackrel{0}{0}\end{array}$ & $\begin{array}{l}m \\
\stackrel{0}{0} \\
0\end{array}$ & $\stackrel{\sim}{a}$ & $\begin{array}{l}0 \\
0 \\
0 \\
0 \\
0\end{array}$ & \begin{tabular}{|l|}
\multirow{2}{*}{} \\
0 \\
$\dot{0}$ \\
1
\end{tabular} & 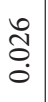 & $\begin{array}{l}\infty \\
\vdots \\
0 \\
0 \\
0\end{array}$ & 离 & $\begin{array}{l}0 \\
0 \\
0 \\
0 \\
1\end{array}$ & $\begin{array}{l}\infty \\
= \\
=\end{array}$ & ڤू & $\stackrel{\text { H }}{\stackrel{\text { m}}{0}}$ \\
\hline$\neg$ & 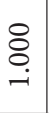 & $\begin{array}{l}0 \\
\text { ஜి } \\
0 \\
0\end{array}$ & $\begin{array}{l}\stackrel{\star}{\infty} \\
\stackrel{0}{ } \\
\stackrel{0}{0}\end{array}$ & 帒 & $\begin{array}{l}\text { to } \\
0 \\
0 \\
-1 \\
1\end{array}$ & $\begin{array}{l}\stackrel{8}{0} \\
\dot{0}\end{array}$ & $\begin{array}{l}\star \\
\infty \\
0 \\
0 \\
0 \\
0 \\
1\end{array}$ & 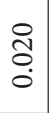 & ô & \begin{tabular}{|l|}
0 \\
0 \\
\multirow{2}{0}{} \\
0 \\
0
\end{tabular} & $\begin{array}{l}0 \\
\vdots \\
0 \\
0\end{array}$ & \begin{tabular}{l}
8 \\
$\check{0}$ \\
\hdashline
\end{tabular} & $\begin{array}{l}0 \\
0 \\
0 \\
0 \\
1 \\
1\end{array}$ & $\begin{array}{l}\hat{o} \\
\dot{0} \\
\dot{\varphi}\end{array}$ & \begin{tabular}{|l|} 
\\
0 \\
0 \\
0 \\
0
\end{tabular} & $\begin{array}{l}\infty \\
\stackrel{2}{-} \\
\end{array}$ & ڤે & $\begin{array}{l}\text { मे } \\
\text { ले } \\
0\end{array}$ \\
\hline & 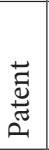 & 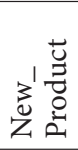 & $\begin{array}{l}\hat{0} \\
0 \\
0 \\
\overrightarrow{0} \\
\bar{n}\end{array}$ & 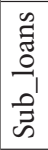 & 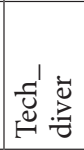 & 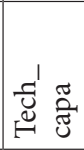 & 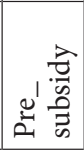 & $\begin{array}{l}z_{0} \\
\tilde{v}_{1} \\
z^{\prime}\end{array}$ & 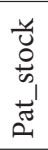 & 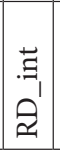 & 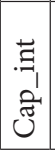 & 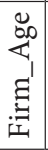 & 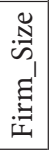 & 党 & 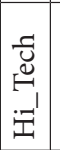 & $\stackrel{0}{0}$ & 芩 & 芫 \\
\hline & - & N & $n$ & $r$ & in & 6 & $n$ & $\infty$ & $a$ & $\circ$ & $\Rightarrow$ & $\simeq$ & 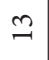 & $\Xi$ & $\stackrel{0}{2}$ & & & \\
\hline
\end{tabular}




\section{Empirical results}

\subsection{Descriptive statistics}

The statistical description and correlation matrix based on the PSM samples are shown in Table 2. The correlation between capital intensity and firm size implies the possibility of multicollinearity. Thus, the variance inflation factor (VIF) test based on ordinary least square regressions is conducted firstly. The variance VIF values from 1.03 to 4.04 (mean $=1.60$ ) when the dependent variable is Patent, and the VIF values from 1.03 to 4.65 (mean $=1.68$ ) when the dependent variable is New_Product. The results indicate no severe multi-collinearity issue.

\subsection{Impacts of direct $R \& D$ grants and subsidized loans on $R \& D$ outputs}

Table 3 illustrates the regression results for the effects of R\&D subsidies (Model $2 \& 5$ ) and the moderating effects of receiving subsidized loans (Model 3 \& 6) on firms' exploratory patent applications and new product sales, respectively. Model 1 and 4 include the control variables only.

Table 3. The impacts of direct R\&D grants and subsidized loans on $R \& D$ outputs

\begin{tabular}{|l|c|c|c|c|c|c|}
\hline & Model 1 & Model 2 & Model 3 & Model 4 & Model 5 & Model 6 \\
\cline { 2 - 7 } & \multicolumn{3}{|c|}{ Dependent variable: Patent } & \multicolumn{2}{c|}{ Dependent variable: New_Product } \\
\hline \multirow{2}{*}{ Tech_diver } & $-0.206^{* * *}$ & $-0.231^{\star * *}$ & $-0.225^{* * *}$ & 0.003 & -0.001 & -0.006 \\
\cline { 2 - 7 } & $(0.051)$ & $(0.050)$ & $(0.050)$ & $(0.021)$ & $(0.021)$ & $(0.021)$ \\
\hline \multirow{2}{*}{ Tech_capa } & -0.006 & -0.017 & -0.011 & -0.008 & -0.010 & -0.012 \\
\cline { 2 - 7 } & $(0.030)$ & $(0.029)$ & $(0.029)$ & $(0.012)$ & $(0.012)$ & $(0.012)$ \\
\hline \multirow{2}{*}{ Pre_subsidy } & -0.045 & -0.056 & -0.077 & -0.042 & -0.020 & -0.025 \\
\cline { 2 - 7 } & $(0.083)$ & $(0.082)$ & $(0.082)$ & $(0.037)$ & $(0.037)$ & $(0.037)$ \\
\hline \multirow{2}{*}{ Hi_edu } & 0.160 & -0.011 & 0.085 & 0.075 & 0.040 & -0.018 \\
\cline { 2 - 7 } & $(0.275)$ & $(0.272)$ & $(0.275)$ & $(0.124)$ & $(0.124)$ & $(0.124)$ \\
\hline \multirow{2}{*}{ Pat_stock } & $2.448^{* * *}$ & $2.414^{* * *}$ & $2.495^{* * *}$ & -0.040 & -0.047 & -0.099 \\
\cline { 2 - 7 } & $(0.432)$ & $(0.425)$ & $(0.427)$ & $(0.203)$ & $(0.202)$ & $(0.202)$ \\
\hline \multirow{2}{*}{ RD_int } & $0.548^{*}$ & 0.501 & 0.490 & 0.119 & 0.100 & 0.095 \\
\cline { 2 - 7 } & $(0.330)$ & $(0.324)$ & $(0.323)$ & $(0.126)$ & $(0.126)$ & $(0.125)$ \\
\hline \multirow{2}{*}{ Cap_int } & $-3.299^{* *}$ & $-3.228^{* *}$ & $-3.269^{* *}$ & -0.323 & -0.264 & -0.219 \\
\cline { 2 - 7 } & $(1.445)$ & $(1.429)$ & $(1.431)$ & $(0.637)$ & $(0.634)$ & $(0.631)$ \\
\hline \multirow{2}{*}{ Firm_Age } & $0.097^{*}$ & $0.105^{*}$ & $0.101^{*}$ & -0.012 & -0.012 & -0.011 \\
\cline { 2 - 7 } & $(0.058)$ & $(0.057)$ & $(0.057)$ & $(0.030)$ & $(0.030)$ & $(0.029)$ \\
\hline \multirow{2}{*}{ Firm_Size } & -0.054 & -0.042 & -0.038 & 0.018 & 0.024 & 0.020 \\
\cline { 2 - 7 } & $(0.107)$ & $(0.105)$ & $(0.105)$ & $(0.050)$ & $(0.050)$ & $(0.050)$ \\
\hline \multirow{2}{*}{ RD_Dpart } & 0.096 & 0.139 & 0.145 & $0.236^{* * *}$ & $0.243^{* * *}$ & $0.239^{* * *}$ \\
\cline { 2 - 7 } & $(0.121)$ & $(0.120)$ & $(0.119)$ & $(0.046)$ & $(0.045)$ & $(0.045)$ \\
\hline
\end{tabular}


End of Table 3

\begin{tabular}{|l|c|c|c|c|c|c|}
\hline \multirow{2}{*}{} & Model 1 & Model 2 & Model 3 & Model 4 & Model 5 & Model 6 \\
\cline { 2 - 7 } & \multicolumn{2}{|c|}{ Dependent variable: Patent } & \multicolumn{2}{c|}{ Dependent variable: New_Product } \\
\hline \multirow{2}{*}{ Hi_Tech } & -0.228 & $-0.257^{\star}$ & $-0.241^{*}$ & -0.000 & -0.010 & -0.017 \\
\cline { 2 - 7 } & $(0.147)$ & $(0.144)$ & $(0.144)$ & $(0.054)$ & $(0.053)$ & $(0.053)$ \\
\hline \multirow{2}{*}{ Subsidy } & & $0.374^{* * *}$ & $0.486^{* * *}$ & & $0.111^{\star * *}$ & $0.062^{\star *}$ \\
\cline { 2 - 7 } & & $(0.066)$ & $(0.077)$ & & $(0.028)$ & $(0.031)$ \\
\hline \multirow{2}{*}{ Sub_loans } & & & 0.123 & & & 0.010 \\
\hline \multirow{2}{*}{$\begin{array}{l}\text { Subsidy } \times \text { Sub_ } \\
\text { loans }\end{array}$} & & & $(0.139)$ & & & $(0.069)$ \\
\hline \multirow{2}{*}{ cons } & 6.407 & 6.016 & 5.838 & 2.339 & 2.278 & 2.279 \\
\hline & $(274.349)$ & $(155.917)$ & $(112.453)$ & $(52.145)$ & $(51.808)$ & $(51.678)$ \\
\hline N & 1398 & 1398 & 1398 & 1118 & 1118 & 1118 \\
\hline firms & 280 & 280 & 280 & 280 & 280 & 280 \\
\hline $\begin{array}{l}\text { Log } \\
\text { likelihood }\end{array}$ & -1369.710 & -1353.206 & -1349.240 & -579.647 & -571.916 & -566.002 \\
\hline Prob > chi2 & 0.0000 & 0.0000 & 0.0000 & 0.0000 & 0.0000 & 0.0000 \\
\hline
\end{tabular}

Note: Standard errors in parentheses; ${ }^{\star} \mathrm{p}<0.1,{ }^{* *} \mathrm{p}<0.05,{ }^{* *} \mathrm{p}<0.01$; All models include a set of industrial, regional and year dummies (not reported).

The coefficient of Subsidy in Model 2 shows that receiving R\&D subsides has a positive effect on firms' exploratory patent applications $(b=0.374, p<0.01)$. The marginal effect shows that, holding all other variables at their means, receiving R\&D subsidies increases firms' exploratory patent applications by 19.2\%. Hypothesis 1a is supported. After adding Sub_loans and its interactive variable with Subsidy, the coefficient of the interaction is significantly negative $(b=-0.412, \mathrm{p}<0.05$, Model 3$)$. This indicates that receiving the $\mathrm{R} \& \mathrm{D}$ subsidized loans will restrain firms' exploratory $\mathrm{R} \& \mathrm{D}$ activities and limit possible novel technological outputs. The marginal effect shows that firms receiving both direct grants and subsidized loans during the same period only increase the exploratory patent applications by $3.7 \%$, with a much lower margin than firms only receiving direct grants (also see Figure 1). Thus, Hypothesis 2a is not supported.

The coefficient of Subsidy in Model 5 shows that receiving R\&D subsidies has a positive effect on firms' new product sales $(b=0.111, \mathrm{p}<0.01)$. The marginal effect shows that receiving $R \& D$ subsidies increases firms' new product sales by $9.8 \%$. Hypothesis $1 \mathrm{~b}$ is supported. Furthermore, the coefficient of the interaction between Sub_loans and Subsidy is significantly positive $(\mathrm{b}=0.177, \mathrm{p}<0.05$, Model 6$)$. This indicates that receiving $R \& D$ subsidized loans will facilitate firms' new product sales and improve the financial returns from $R \& D$ activities. The marginal effect shows that firms receiving both direct grants and subsidized loans can increase the new product sales by $21.2 \%$, higher than those only receiving direct grants (also see Figure 2). Thus, Hypothesis $2 \mathrm{~b}$ is supported. 


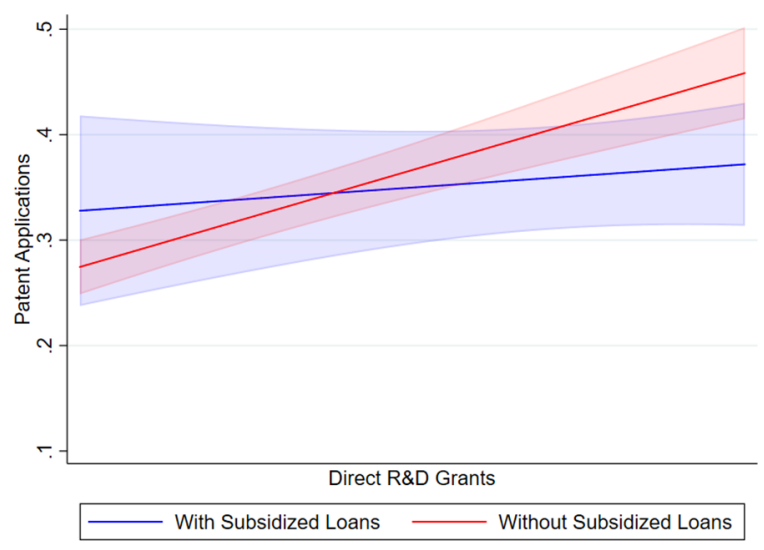

Figure 1. The effects of R\&D subsidies on exploratory patent applications

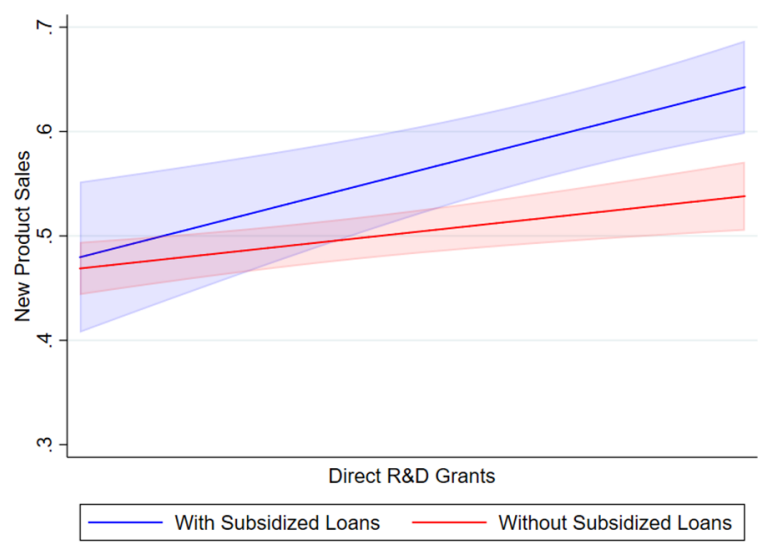

Figure 2. The effects of R\&D subsidies on new product sales

\subsection{Robustness check}

A two-step robustness check is carried out to provide additional support to the empirical results. First, all the variables are kept and the regressions are re-run by adopting the standard panel data models with fixed effects. The panel data regressions with fixed effects can eliminate alternative explanations driven by the differences between firms and correct for omitted-variable bias (Benner \& Tushman, 2002). To deal with the potential endogeneity issue, an instrumental variable (IV) is also set for the R\&D subsidy and the fixed-effect regressions with generalized method of moments (GMM) are performed. Following the suggestion of Guo et al. (2016), we employ the natural logarithm of total investment in fixed assets made by local governments at the city level as the instrumental variable. This IV is related to the probability of a firm's winning public R\&D subsidy and has significant effect on the distribution of direct R\&D grants, but unrelated with unobserved variables that affect firm-level R\&D inputs and outputs. The data is obtained from the China Statistical Yearbook on Science and Technology (2011-2015). 
Table 4. The robustness check by adopting standard panel data models with fixed effects

\begin{tabular}{|c|c|c|c|c|c|c|c|c|}
\hline & Model 7 & Model 8 & Model 9 & Model 10 & Model 11 & Model 12 & $\begin{array}{c}\text { Model } \\
13\end{array}$ & Model 14 \\
\hline & \multicolumn{4}{|c|}{ Dependent variable: Patent } & \multicolumn{4}{|c|}{ Dependent variable: New_Product } \\
\hline & & IV-GMM & & IV-GMM & & IV-GMM & & IV-GMM \\
\hline \multirow{2}{*}{$\begin{array}{l}\text { Tech__ } \\
\text { diver }\end{array}$} & $-0.318^{\star * *}$ & $-0.293^{* * *}$ & $-0.317^{\star * *}$ & $-0.121^{\star \star \star}$ & -0.006 & 0.021 & 0.000 & -0.007 \\
\hline & $(0.025)$ & $(0.027)$ & $(0.025)$ & $(0.028)$ & $(0.023)$ & $(0.023)$ & $(0.018)$ & $(0.017)$ \\
\hline \multirow{2}{*}{ Tech_capa } & -0.047 & -0.015 & -0.050 & -0.061 & $-0.120^{*}$ & $-0.133^{* *}$ & $-0.084^{*}$ & -0.028 \\
\hline & $(0.070)$ & $(0.069)$ & $(0.070)$ & $(0.058)$ & $(0.064)$ & $(0.060)$ & $(0.051)$ & $(0.041)$ \\
\hline \multirow{2}{*}{$\begin{array}{l}\text { Pre } \\
\text { subsidy }\end{array}$} & -0.071 & 0.163 & -0.069 & -0.025 & 0.007 & $0.176^{*}$ & -0.008 & -0.016 \\
\hline & $(0.049)$ & $(0.168)$ & $(0.049)$ & $(0.034)$ & $(0.043)$ & $(0.106)$ & $(0.031)$ & $(0.044)$ \\
\hline \multirow{2}{*}{ Hi_edu } & -0.138 & -0.119 & -0.136 & -0.081 & 0.043 & 0.049 & 0.005 & -0.062 \\
\hline & $(0.159)$ & $(0.166)$ & $(0.159)$ & $(0.130)$ & $(0.168)$ & $(0.148)$ & $(0.112)$ & $(0.093)$ \\
\hline \multirow{2}{*}{ Pat_stock } & $0.836^{\star *}$ & $0.921^{\star * *}$ & $0.833^{* *}$ & $0.629^{* * *}$ & 0.098 & 0.251 & -0.039 & -0.077 \\
\hline & $(0.377)$ & $(0.259)$ & $(0.376)$ & $(0.182)$ & $(0.217)$ & $(0.229)$ & $(0.169)$ & $(0.140)$ \\
\hline \multirow{2}{*}{ RD_int } & $0.244^{*}$ & 0.211 & $0.245^{\star}$ & 0.103 & -0.022 & -0.035 & 0.051 & 0.123 \\
\hline & $(0.148)$ & $(0.156)$ & $(0.148)$ & $(0.137)$ & $(0.155)$ & $(0.126)$ & $(0.118)$ & $(0.094)$ \\
\hline \multirow{2}{*}{ Cap_int } & $-1.226^{\star \star}$ & $-1.138^{\star}$ & $-1.252^{\star \star}$ & -0.689 & -0.595 & -0.461 & -0.252 & -0.152 \\
\hline & $(0.603)$ & $(0.684)$ & $(0.605)$ & $(0.544)$ & $(0.901)$ & $(0.682)$ & $(0.688)$ & $(0.455)$ \\
\hline \multirow{2}{*}{ Firm_Age } & $0.138^{\star}$ & 0.070 & $0.137^{\star}$ & 0.036 & -0.083 & -0.114 & -0.011 & 0.013 \\
\hline & $(0.072)$ & $(0.089)$ & $(0.072)$ & $(0.023)$ & $(0.062)$ & $(0.087)$ & $(0.025)$ & $(0.019)$ \\
\hline \multirow{2}{*}{ Firm_Size } & -0.071 & -0.083 & -0.074 & 0.003 & 0.037 & 0.046 & 0.016 & 0.037 \\
\hline & $(0.073)$ & $(0.073)$ & $(0.072)$ & $(0.046)$ & $(0.082)$ & $(0.067)$ & $(0.049)$ & $(0.038)$ \\
\hline \multirow{2}{*}{ RD_Dpart } & 0.054 & 0.064 & 0.055 & 0.102 & $0.207^{\star * *}$ & $0.218^{\star \star *}$ & $0.185^{\text {***}}$ & $0.144^{\star * *}$ \\
\hline & $(0.048)$ & $(0.054)$ & $(0.049)$ & $(0.062)$ & $(0.048)$ & $(0.045)$ & $(0.039)$ & $(0.038)$ \\
\hline \multirow{2}{*}{ Hi_Tech } & -0.045 & -0.056 & -0.042 & -0.077 & 0.015 & -0.037 & 0.006 & -0.011 \\
\hline & $(0.069)$ & $(0.062)$ & $(0.070)$ & $(0.059)$ & $(0.051)$ & $(0.047)$ & $(0.044)$ & $(0.040)$ \\
\hline \multirow{2}{*}{ Subsidy } & $0.093^{* *}$ & $0.493^{*}$ & $0.107^{\star *}$ & $0.747^{\star *}$ & $0.098^{\star * *}$ & $0.427^{\star}$ & $0.053^{\star}$ & -0.045 \\
\hline & $(0.040)$ & $(0.269)$ & $(0.044)$ & $(0.365)$ & $(0.037)$ & $(0.222)$ & $(0.027)$ & $(0.242)$ \\
\hline \multirow{2}{*}{ Sub_loans } & & & -0.002 & $-0.238^{\star}$ & & & 0.008 & -0.077 \\
\hline & & & $(0.036)$ & $(0.135)$ & & & $(0.059)$ & $(0.090)$ \\
\hline \multirow{2}{*}{$\begin{array}{l}\text { Subsidy } \times \\
\text { Sub_loans }\end{array}$} & & & -0.039 & $-0.106^{*}$ & & & $0.136^{*}$ & $0.461^{\star * *}$ \\
\hline & & & $(0.066)$ & $(0.062)$ & & & $(0.070)$ & $(0.040)$ \\
\hline \multirow{2}{*}{ _cons } & 0.717 & 0.602 & 0.742 & $1.234^{* *}$ & $0.886^{*}$ & 0.167 & $0.789^{\star * *}$ & 0.259 \\
\hline & $(0.454)$ & $(0.414)$ & $(0.454)$ & $(0.519)$ & $(0.478)$ & $(0.392)$ & $(0.292)$ & $(0.335)$ \\
\hline $\mathrm{N}$ & 1398 & 1398 & 1398 & 1398 & 1118 & 1118 & 1118 & 1118 \\
\hline Firms & 280 & 280 & 280 & 280 & 280 & 280 & 280 & 280 \\
\hline Prob > F & 0.0000 & 0.0000 & 0.0000 & 0.0000 & 0.0000 & 0.0000 & 0.0000 & 0.0000 \\
\hline
\end{tabular}

Note: Robust Standard errors clustered by firms in parentheses; ${ }^{*} p<0.1$, ${ }^{* *} \mathrm{p}<0.05,{ }^{* * *} \mathrm{p}<0.01$; All models include a set of industrial, regional and year dummies (not reported); for IV regression, Underidentification test: 24.380 (Model 8), 19.275 (Model 12) Chi-sq (1) P-val $=0.0000 ; 5)$ Weak identification test (Cragg-Donald Wald F statistic): 24.656 (Model 8), 19.446 (Model 12), Stock-Yogo weak ID test critical values: $10 \%$ maximal IV size is 16.38 . 
Table 4 illustrates the results of the robustness check for the effects of R\&D subsidies (Model 7 \& 11) and the heterogeneous effects of the subsidies combined with subsidized loans (Model 9 \& 13) on firms' exploratory patent applications and new product sales, respectively. Model 8 and 12 report the IV-GMM regressions for the effect of R\&D subsides, and Model 10 and 14 report the IV-GMM regressions for the moderating effect of simultaneously receiving subsidized loans. All the results by adopting standard panel data regressions are consistent with the results of the panel data Tobit regressions.

Second, the endogenous treatment effects regressions based on the full sample are adopted. The endogenous treatment effects regression takes care of the self-selection bias derived from unobservable variables that PSM method can hardly handle. The estimated results, reported in Table 5, are almost identical to the results from the panel data Tobit regressions, providing additional supports for the empirical results.

Table 5. The endogenous treatment effects regressions

\begin{tabular}{|c|c|c|c|c|}
\hline & Model 15 & Model 16 & Model 17 & Model 18 \\
\hline & \multicolumn{2}{|c|}{ Dependent variable: Patent } & \multicolumn{2}{|c|}{ Dependent variable: New_Product } \\
\hline \multirow{2}{*}{ Tech_diver } & 0.024 & 0.031 & -0.005 & -0.006 \\
\hline & $(0.115)$ & $(0.115)$ & $(0.010)$ & $(0.010)$ \\
\hline \multirow{2}{*}{ Tech_capa } & -0.355 & -0.353 & $0.054^{*}$ & $0.056^{* *}$ \\
\hline & $(0.222)$ & $(0.222)$ & $(0.028)$ & $(0.028)$ \\
\hline \multirow{2}{*}{ Pre_subsidy } & $-0.706^{* * *}$ & $-0.711^{* * *}$ & 0.020 & 0.024 \\
\hline & $(0.168)$ & $(0.167)$ & $(0.020)$ & $(0.021)$ \\
\hline \multirow{2}{*}{ Hi_edu } & $1.663^{* * *}$ & $1.691^{\star * *}$ & -0.064 & -0.074 \\
\hline & $(0.407)$ & $(0.396)$ & $(0.053)$ & $(0.053)$ \\
\hline \multirow{2}{*}{ Pat_stock } & $7.145^{\star * \star}$ & $7.145^{\star * *}$ & 0.019 & 0.013 \\
\hline & $(1.955)$ & $(1.955)$ & $(0.077)$ & $(0.077)$ \\
\hline \multirow{2}{*}{ RD_int } & $-1.114^{\star}$ & $-1.124^{*}$ & $0.257^{\star * *}$ & $0.255^{\star * *}$ \\
\hline & $(0.658)$ & $(0.655)$ & $(0.079)$ & $(0.079)$ \\
\hline \multirow{2}{*}{ Cap_int } & $6.216^{\star *}$ & $6.268^{\star *}$ & 0.106 & 0.087 \\
\hline & $(2.785)$ & $(2.781)$ & $(0.250)$ & $(0.260)$ \\
\hline \multirow{2}{*}{ Firm_Age } & -0.217 & -0.217 & 0.002 & 0.002 \\
\hline & $(0.147)$ & $(0.147)$ & $(0.015)$ & $(0.015)$ \\
\hline \multirow{2}{*}{ Firm_Size } & $1.361^{* * *}$ & $1.364^{* * *}$ & 0.019 & 0.017 \\
\hline & $(0.171)$ & $(0.171)$ & $(0.016)$ & $(0.016)$ \\
\hline \multirow{2}{*}{ RD_Dpart } & 0.252 & 0.250 & $0.140^{\star \star \star}$ & $0.140^{\star \star \star}$ \\
\hline & $(0.169)$ & $(0.169)$ & $(0.019)$ & $(0.019)$ \\
\hline \multirow{2}{*}{ Hi_Tech } & $-0.557^{\star \star}$ & $-0.556^{\star \star}$ & 0.010 & 0.007 \\
\hline & $(0.236)$ & $(0.235)$ & $(0.025)$ & $(0.025)$ \\
\hline \multirow{2}{*}{ Subsidy } & $0.738^{\star *}$ & $1.045^{\star * \star}$ & $0.096^{\star * *}$ & 0.048 \\
\hline & $(0.297)$ & $(0.316)$ & $(0.034)$ & $(0.036)$ \\
\hline
\end{tabular}


End of Table 5

\begin{tabular}{|l|c|c|c|c|}
\hline \multirow{2}{*}{ Sub_loans } & & 0.659 & & 0.023 \\
\cline { 2 - 5 } & & $(0.572)$ & & $(0.045)$ \\
\hline \multirow{2}{*}{$\begin{array}{l}\text { Subsidy } \times \text { Sub_ } \\
\text { loans }\end{array}$} & & $-1.251^{* *}$ & & $0.135^{* *}$ \\
\hline \multirow{2}{*}{ cons } & $-7.247^{* * *}$ & $-7.253^{* * *}$ & 0.038 & $0.055)$ \\
\cline { 2 - 5 } & $(1.101)$ & $(1.101)$ & $(0.240)$ & 0.046 \\
\hline $\mathrm{N}$ & 6362 & 6362 & 5088 & 5088 \\
\hline firms & 1,273 & 1,273 & 1,273 & 1,273 \\
\hline Log likelihood & -18640.439 & -18636.227 & -3375.580 & -3365.279 \\
\hline Prob > chi2 & 0.0000 & 0.0000 & 0.0000 & 0.0000 \\
\hline
\end{tabular}

Note: robust standard errors clustered by firms are in parentheses; ${ }^{\star} \mathrm{p}<0.1,{ }^{* *} \mathrm{p}<0.05,{ }^{* *} \mathrm{p}<0.01$; All models include a set of industrial, regional and year dummies (not reported).

\section{Discussion}

According to the empirical results, obtaining R\&D subsidies in general can promote the $\mathrm{R} \& \mathrm{D}$ outputs, i.e., exploratory patent applications and new product sales, of the aided firms. Compared with receiving direct grants alone, if a firm also obtains subsidized loans, its new product sales will be greatly increased. On the contrary, the exploratory patent applications of firms receiving subsidized loans is significantly less than that of firms supported solely by direct R\&D grant.

The results imply that firms are less likely to use subsidized loans in R\&D activities with higher risks but better innovativeness, to pursue exploratory patents incorporating novel technological knowledge. Instead, firms are more inclined to wield subsidized loans in product development and commercialization activities in exchange for economic benefits. This result strongly supports Hottenrott and Richstein (2020)'s findings based on the German hightech start-ups. Therefore, in China, the heterogeneity of direct R\&D grants and subsidized loans may be more in line with the cost-expected return logic (Hottenrott \& Richstein, 2020).

The empirical results of this study collide with Guan and Yam's arguments (2015) that neither direct $R \& D$ grants nor special loans have significantly positive effects on Chinese firms' patent applications. The disparate research findings could be ascribed to the different development stages of China's economic transition, the growth of Chinese firms' R\&D capabilities, and the change of government's requirement on the utilization of R\&D subsidy. Guan and Yam's research is based on a data of the mid-1990s, when China was experiencing the initial national economic transition, firms' technology levels were laggard, and the Chinese government focused more on the economic catching up (Liu et al., 2017). Under such contexts, firms may use R\&D subsidy in exchange for economic benefits such as expanding production scale or quick development of new products through imitating foreign enterprises. Moreover, the relatively weak intellectual property regime in China back then (Liu \& White, 2001) also dimmed the role of subsidy in promoting firms' patent application. In this research, after decades of development including the remarkable technological catching-up, 
Chinese firms' technological innovation capabilities are greatly enhanced, and the Chinese government has shifted their focus more to the indigenous innovation (Liu et al., 2017). Thus, the effects of R\&D subsidy on firm's R\&D outputs, especially in terms of patent applications, has changed over the years.

\section{Conclusions}

This study examines the effects of direct grants and subsidized loans on firms' R\&D outputs, in terms of exploratory patent applications and new product sales from firms' R\&D activities. By conducting an empirical study based on the data of manufacturing firms from Jiangsu Province, China, this study reinforces and supplements literature on R\&D subsidized loans.

A key theoretical contribution of this study is extending the knowledge on public R\&D subsidies by considering the contingency effects associated with subsidy types. This study also furthers the research on R\&D subsidized loans in transition economies such as China. Moreover, this study contributes to the understandings on the relationship between governmental support and firms' innovation in transitional economies.

This study has several important policy implications. China has achieved marvelous economic growth from the factor-driven development at its first economic reform. China is now at an important transition point to shift from factor-driven to innovation-driven. China should prepare for this "intellectual revolution". At first, Chinese government should encourage firms' technological upgrade and link the technological research to the market. Thus, the rational utilization of subsidized loans should be further encouraged. The implementation of this demand-oriented policies can help China to tackle the shortage of traditional supply-side policies. Combining policy tools such as public R\&D grants and subsidized loans together as a package might be a highlight to provide efficient support for firms' R\&D activities in China. By exploiting the advantages while offsetting their own faults, a combined subsidy package triggers better positive effects on firm's R\&D activities. Second, China should cultivate a more favorable environment for firm-level innovation. The government can enhance its capabilities in public intervention by introducing more market principles in the screening and monitoring process of $\mathrm{R} \& \mathrm{D}$ subsidized loans. When designing subsidy schemes, the government should introduce market-oriented principles in the screening and monitoring processes of R\&D subsidized loans, to stay compatible with the commercial banks. This collaterally advances governments' capability in public intervention through R\&D subsidies. In particular, governments could formulate and revise the evaluation protocols to provide flexibilities to firms on the innovation directions. In addition, policy makers should set policies that facilitate firms' access to other external financing channels to release some of the pressure from bank loans. These policy implications are also important to other transitional economies.

This research also points out several potentials for further studies. First, the disclosure of the dataset by Jiangsu government which is adopted in this study has been discontinued after 2014. Future research can expand the length of the sample period and investigate the impacts of different $R \& D$ subsidy types on firms. For example, after undertaking explorative R\&D activities and producing exploratory patents, it is worth knowing whether the subsidy recipients will gain profits from those patents by means such as licensing or transferring 
patent rights. Second, as different levels of governments may follow different principles and logics in designing and allocating $\mathrm{R} \& \mathrm{D}$ subsidies, a comparison between the effects of $\mathrm{R} \& \mathrm{D}$ subsidies from central and local governments deserves systematic investigation. Third, research on the effects of R\&D subsidy on firms' behaviors, e.g., behavior change during the $\mathrm{R} \& \mathrm{D}$ process, has become increasingly important. Thus, future studies on behavior change may further unfold the black box of the mechanism of how R\&D subsidies take effect. As discussed above, the measurement of technological output in this study, i.e. patent with novel knowledge, reveals firms' exploratory innovation attempts. Possible future studies could look into the influences of different types of R\&D subsidies on exploration and exploitation, and how combined subsidy schemes may motivate firms' ambidexterity.

\section{Notations}

1. On February 9, 2006, the State Council formulated the Outline of the National Mediumand Long-Term Science and Technology Development Planning (2006-2020). It pointed out clearly that, by 2020, the general objective of China's science and technology development is to significantly enhance the ability of indigenous innovation, to promote the economic and social development, and to safeguard the national security.

2. 2019 China Statistical Yearbook on Science and Technology (in Chinese).

3. Handbook of Policies towards Firm's Technological Innovation (in Chinese).

4. The official information on the subsidized projects in the specific R\&D subsidy program, which this study focuses on, is only released to 2014. Meanwhile, Jiangsu Government only discloses the survey data up to 2014. No further updates are available.

5. Interim Regulation on the Administration of Scientific and Technological Small and Medium-sized Firms' Innovation Fund in Jiangsu Province (Jiangsu Science and Technology Department, 2007, No. 79; Jiangsu Finance Department, 2007, No. 26, in Chinese).

6. Notice of Jiangsu provincial government on several policies of encouraging and promoting scientific and technological innovation and entrepreneurship (Jiangsu Provincial People’s Government, 2006, No. 53, in Chinese).

\section{Acknowledgements}

This work is supported by the China Postdoctoral Science Foundation (2018M641397), the National Natural Science Foundation of China (Grant No. 71932009), and the National Social Science Fund of China (No. 20\&ZD075). We thank the editor and two anonymous referees for their guidance and constructive comments.

\section{Funding}

This work is supported by the China Postdoctoral Science Foundation (2018M641397), the National Natural Science Foundation of China (Grant No. 71932009) and the National Social Science Fund of China (No. 20\&ZD075). 


\section{Author contributions}

Yuchen Gao conceived the study; Yuchen Gao and Si Zhang were responsible for the design and development of the data analysis; Yuchen Gao and Yimei Hu were responsible for data collection and analysis; Yuchen Gao and Si Zhang were responsible for data interpretation; Yuchen Gao wrote the first draft of the manuscript; Si Zhang and Yimei Hu reviewed and revised the manuscript.

\section{Disclosure statement}

No conflict of interest exits in the submission of this manuscript, and manuscript is approved by all authors for publication. The work is original research that has not been published previously, and not under consideration for publication elsewhere, in whole or in part. All the authors listed have approved the manuscript that is enclosed.

\section{References}

Ahuja, G., \& Lampert, M. C. (2001). Entrepreneurship in the large corporation: A longitudinal study of how established firms create breakthrough inventions. Strategic Management Journal, 22(6-7), 521-543. https://doi.org/10.1002/smj.176

Antonelli, C., \& Crespi, F. (2013). The "Matthew effect" in R\&D public subsidies: The Italian evidence. Technological Forecasting and Social Change, 80(8), 1523-1534. https://doi.org/10.1016/j.techfore.2013.03.008

Arrow, K. (1962). Economic welfare and the allocation of resources for invention. In R. R. Nelson (Ed.), The rate and direction of inventive activity: Economic and social factors (pp. 609-626). Princeton University Press. https://doi.org/10.1515/9781400879762-024

Beck, M., Lopes-Bento, C., \& Schenker-Wicki, A. (2016). Radical or incremental: Where does R\&D policy hit? Research Policy, 45(4), 869-883. https://doi.org/10.1016/j.respol.2016.01.010

Benner, M. J., \& Tushman, M. (2002). Process management and technological innovation: A longitudinal study of the photography and paint industries. Administrative Science Quarterly, 47(4), 676-706. https://doi.org/10.2307/3094913

Bertoni, F., Martí, J., \& Reverte, C. (2019). The impact of government-supported participative loans on the growth of entrepreneurial ventures. Research Policy, 48(1), 371-384. https://doi.org/10.1016/j.respol.2018.09.006

Boeing, P. (2016). The allocation and effectiveness of China's R\&D subsidies - Evidence from listed firms. Research Policy, 45(9), 1774-1789. https://doi.org/10.1016/j.respol.2016.05.007

Bronzini, R., \& Piselli, P. (2016). The impact of R\&D subsidies on firm innovation. Research Policy, 45(2), 442-457. https://doi.org/10.1016/j.respol.2015.10.008

Chapman, G., \& Hewitt-Dundas, N. (2018). The effect of public support on senior manager attitudes to innovation. Technovation, 69, 28-39. https://doi.org/10.1016/j.technovation.2017.10.004

Clarysse, B., Wright, M., \& Mustar, P. (2009). Behavioural additionality of R\&D subsidies: A learning perspective. Research Policy, 38(10), 1517-1533. https://doi.org/10.1016/j.respol.2009.09.003

David, P. A., Hall, B. H., \& Toole, A. A. (2000). Is public R\&D a complement or substitute for private R\&D? A review of the econometric evidence. Research Policy, 29(4-5), 497-529.

https://doi.org/10.1016/S0048-7333(99)00087-6 
Dimos, C., \& Pugh, G. (2016). The effectiveness of R\&D subsidies: A meta-regression analysis of the evaluation literature. Research Policy, 45(4), 797-815. https://doi.org/10.1016/j.respol.2016.01.002

Dixit, A. (1997). Power of incentives in private versus public organizations. The American Economic Review, 87(2), 378-382.

Grau, T., Huo, M., \& Neuhoff, K. (2012). Survey of photovoltaic industry and policy in Germany and China. Energy Policy, 51, 20-37. https://doi.org/10.1016/j.enpol.2012.03.082

Griliches, Z. (1990). Patent statistics as economic indicators: A survey. Journal of Economic Literature, 28(4), 1661-1707. https://www.jstor.org/stable/2727442

Guan, J., \& Yam, R. C. M. (2015). Effects of government financial incentives on firms' innovation performance in China: Evidences from Beijing in the 1990s. Research Policy, 44(1), 273-282. https://doi.org/10.1016/j.respol.2014.09.001

Guo, D., Guo, Y., \& Jiang, K. (2016). Government-subsidized R\&D and firm innovation: Evidence from China. Research Policy, 45(6), 1129-1144. https://doi.org/10.1016/j.respol.2016.03.002

Hall, B., \& Van Reenen, J. (2000). How effective are fiscal incentives for R\&D? A review of the evidence. Research Policy, 29(4-5), 449-469. https://doi.org/10.1016/S0048-7333(99)00085-2

Hall, R. (1992). The strategic analysis of intangible resources. Strategic Management Journal, 13(2), 135-144. https://doi.org/10.1002/smj.4250130205

Hottenrott, H., \& Richstein, R. (2020). Start-up subsidies: Does the policy instrument matter? Research Policy, 49(1), 103888. https://doi.org/10.1016/j.respol.2019.103888

Huang, Q., Jiang, M. S., \& Miao, J. (2016). Effect of government subsidization on Chinese Industrial firms' technological innovation efficiency: A stochastic frontier analysis. Journal of Business Economics and Management, 17(2), 187-200. https://doi.org/10.3846/16111699.2015.1061590

Huergo, E., Trenado, M., \& Ubierna, A. (2016). The impact of public support on firm propensity to engage in R\&D: Spanish experience. Technological Forecasting and Social Change, 113(B), 206-219. https://doi.org/10.1016/j.techfore.2015.05.011

Huergo, E., \& Moreno, L. (2017). Subsidies or loans? Evaluating the impact of R\&D support programmes. Research Policy, 46(7), 1198-1214. https://doi.org/10.1016/j.respol.2017.05.006

Huergo, E., \& Trenado, M. (2010). The application for and the awarding of low-interest credits to finance R\&D projects. Review of Industrial Organization, 37(3), 237-259. https://doi.org/10.1007/s11151-010-9263-7

Hussinger, K. (2008). R\&D and subsidies at the firm level: An application of parametric and semiparametric two-step selection models. Journal of Applied Econometrics, 23(6), 729-747. https://doi.org/10.1002/jae.1016

Jia, N., Huang, K. G., \& Zhang, C. M. (2019). Public governance, corporate governance, and firm innovation: An examination of state-owned enterprises. Academy of Management Journal, 62(1), 220-247. https://doi.org/10.5465/amj.2016.0543

Jiang, G. G., Wang, D., \& Chen, J. (2012). Market analysis and policy design of LED industry in Jiangsu Province. Advanced Materials Research, 512-515, 2705-2708. https://doi.org/10.4028/www.scientific.net/AMR.512-515.2705

Jourdan, J., \& Kivleniece, I. (2017). Too much of a good thing? The dual effect of public sponsorship on organizational performance. Academy of Management Journal, 60(1), 55-77. https://doi.org/10.5465/amj.2014.1007

Lach, S. (1995). Patents and productivity growth at the industry level: A first look. Economics Letters, 49(1), 101-108. https://doi.org/10.1016/0165-1765(94)00618-C

Li, J., Xia, J., \& Zajac, E. J. (2018). On the duality of political and economic stakeholder influence on firm innovation performance: Theory and evidence from Chinese firms. Strategic Management Journal, 39(1), 193-216. https://doi.org/10.1002/smj.2697 
Liang, L. H. (2014, June). Analysis the new pattern of solar PV industry development in China and the enlightenment from Germany. In 2014 IEEE $9^{\text {th }}$ Conference on Industrial Electronics and Applications (ICIEA) (pp. 550-555). Hangzhou, China. IEEE. https://doi.org/10.1109/ICIEA.2014.6931225

Liu, X. L., \& White, S. (2001). Comparing innovation systems: A framework and application to China’s transitional context. Research Policy, 30(7), 1091-1114. https://doi.org/10.1016/S0048-7333(00)00132-3

Liu, X., Li, X., \& Li, H. (2016). R\&D subsidies and business R\&D: Evidence from high-tech manufacturing firms in Jiangsu. China Economic Review, 41, 1-22. https://doi.org/10.1016/j.chieco.2016.08.003

Liu, X., Schwaag Serger, S., Tagscherer, U., \& Chang, A. Y. (2017). Beyond catch-up - can a new innovation policy help China overcome the middle income trap? Science and Public Policy, 44(5), 656-669. https://doi.org/10.1093/scipol/scw092

Manso, G. (2011). Motivating Innovation. The Journal of Finance, 66(5), 1823-1860. https://doi.org/10.1111/j.1540-6261.2011.01688.x

Nelson, R. R. (1959). The simple economics of basic scientific research. Journal of Political Economy, 67(3), 297-306. https://doi.org/10.1086/258177

Perez-Sebastian, F. (2015). Market failure, government inefficiency, and optimal R\&D policy. Economics Letters, 128, 43-47. https://doi.org/10.1016/j.econlet.2015.01.012

Rangan, S., Samii, R., \& Van Wassenhove, L. N. (2006). Constructive partnerships: When alliances between private firms and public actors can enable creative strategies. Academy of Management Review, 31(3), 738-751. https://doi.org/10.5465/amr.2006.21318928

Tang, Y., Hu, X., Petti, C., \& Thürer, M. (2019). Institutional incentives and pressures in Chinese manufacturing firms' innovation. Management Decision, 58(5), 812-827. https://doi.org/10.1108/MD-08-2018-0933

Teachman, J. D. (1980). Analysis of population diversity: Measures of qualitative variation. Sociological Methods \& Research, 8(3), 341-362. https://doi.org/10.1177/004912418000800305

Verona, G. (1999). A resource-based view of product development. Academy of Management Review, 24(1), 132-142. https://doi.org/10.5465/amr.1999.1580445

Wang, Y., Li, J., \& Furman, J. L. (2017). Firm performance and state innovation funding: Evidence from China's Innofund program. Research Policy, 46(6), 1142-1161. https://doi.org/10.1016/j.respol.2017.05.001

Wernerfelt, B. (1984). A resource-based view of the firm. Strategic Management Journal, 5(2), 171-180. https://doi.org/10.1002/smj.4250050207

Xin, F., Zhang, J., Chen, Z., \& Du, X. (2016). Do the types of subsidies and firms' heterogeneity affect the effectiveness of public R\&D subsidies? Evidence from China's Innofund programme. Asian Journal of Technology Innovation, 24(3), 317-337. https://doi.org/10.1080/19761597.2016.1256705

Zhao, B., \& Ziedonis, R. (2020). State governments as financiers of technology startups: Evidence from Michigan's R\&D loan program. Research Policy, 49(4), 103926. https://doi.org/10.1016/j.respol.2020.103926

Zheng, W., Singh, K., \& Mitchell, W. (2015). Buffering and enabling: The impact of interlocking political ties on firm survival and sales growth. Strategic Management Journal, 36(11), 1615-1636. https://doi.org/10.1002/smj.2301

Zhou, J., Li, J., Jiao, H., Qiu, H., \& Liu, Z. (2020). The more funding the better? The moderating role of knowledge stock on the effects of different government-funded research projects on firm innovation in Chinese cultural and creative industries. Technovation, 92-93, 102059. https://doi.org/10.1016/j.technovation.2018.11.002

Zuniga-Vicente, J. A., Alonso-Borrego, C., Forcadell, F. J., \& Galan, J. I. (2014). Assessing the effect of public subsidies on firm R\&D investment: A survey. Journal of Economic Surveys, 28(1), 36-67. https://doi.org/10.1111/j.1467-6419.2012.00738.x 


\section{APPENDIX}

\section{A.1. PSM sampling}

Table A.1. PSM variables

\begin{tabular}{|c|c|c|}
\hline Variables & Measurement & Note \\
\hline \multicolumn{3}{|c|}{ Treatment variable } \\
\hline $\begin{array}{l}\text { Public_ } \\
\text { project }\end{array}$ & $\begin{array}{l}\text { If a firm participates in the } \\
\text { innovation fund for SMEs }\end{array}$ & PSM treatment variable \\
\hline \multicolumn{3}{|l|}{ Covariates } \\
\hline Tech_capa & $\begin{array}{l}\text { The ratio of intangible assets to total } \\
\text { asset }\end{array}$ & Firms' technological potential \\
\hline $\begin{array}{l}\text { Pre } \\
\text { subsidy }\end{array}$ & $\begin{array}{l}\text { The prior experience of Participation } \\
\text { in R\&D subsidy programs in the } \\
\text { three years before } 2010\end{array}$ & $\begin{array}{l}\text { To affect the subsequent R\&D subsidy } \\
\text { receiving }\end{array}$ \\
\hline Hi_edu & $\begin{array}{l}\text { The proportion of employees with a } \\
\text { bachelor's degree or above in the total } \\
\text { number of employees }\end{array}$ & $\begin{array}{l}\text { Screening criteria: at least } 30 \% \text { own college } \\
\text { degree or the above }\end{array}$ \\
\hline RD_int & $\begin{array}{l}\text { The ratio of R\&D expenditure on } \\
\text { firms' total sales at the certain year }\end{array}$ & $\begin{array}{l}\text { Screening criteria: high-tech SMEs whose } \\
\text { annual R\&D expenditure is no less than } 3 \% \text { of } \\
\text { the annual sales }\end{array}$ \\
\hline Cap_int & $\begin{array}{l}\text { The natural logarithm of net fixed } \\
\text { assets divided by the number of } \\
\text { employees }\end{array}$ & $\begin{array}{l}\text { Screening criteria: strong market } \\
\text { competitiveness and economic potential }\end{array}$ \\
\hline RD_Dpart & $\begin{array}{l}\text { Whether firms have their R\&D } \\
\text { institutions or not }\end{array}$ & Formal R\&D regulations of firms. \\
\hline Firm_Size & $\begin{array}{l}\text { The natural logarithm of the number } \\
\text { of employees }\end{array}$ & $\begin{array}{l}\text { Screening criteria: have no more than } 500 \\
\text { employees }\end{array}$ \\
\hline $\begin{array}{l}\text { Dummy_ } \\
\text { industry }\end{array}$ & dummies & Based on 2-digit industrial codes \\
\hline $\begin{array}{l}\text { Dummy_ } \\
\text { region }\end{array}$ & dummies & $\begin{array}{l}\text { Based on firms' locations south, north, and } \\
\text { central areas of Jiangsu }\end{array}$ \\
\hline
\end{tabular}

Table A.2. Significance T-test for non-recipients and recipients of subsidized loans

\begin{tabular}{|l|c|c|c|c|}
\hline & \multicolumn{2}{|c|}{ Means } & \multicolumn{2}{c|}{ t-test } \\
\hline \multicolumn{1}{|c|}{ Covariates } & $\begin{array}{c}\text { Without } \\
\text { subsidized loans }\end{array}$ & $\begin{array}{c}\text { With } \\
\text { subsidized loans }\end{array}$ & $\mathrm{t}$ & $\mathrm{p}>\mathrm{t}$ \\
\hline Tech_Capa & 0.213 & 0.243 & -0.579 & 0.564 \\
\hline Pre_subsidy & 0.020 & 0.049 & -0.920 & 0.359 \\
\hline Hi_edu & 0.134 & 0.171 & -1.653 & 0.101 \\
\hline RD_int & 0.070 & 0.088 & -0.806 & 0.421 \\
\hline Cap_int & 0.072 & 0.062 & 1.434 & 0.154 \\
\hline RD_Dpart & 0.889 & 0.878 & 0.182 & 0.856 \\
\hline Firm_Size & 5.064 & 5.193 & -1.194 & 0.235 \\
\hline
\end{tabular}


Table A.3. The Probit Regression for the PSM

\begin{tabular}{|c|c|c|}
\hline & Model A1 & Model A2 \\
\hline & Pre-PSM & Post-PSM \\
\hline \multirow{2}{*}{ Tech_Capa } & 0.165 & -0.110 \\
\hline & $(0.183)$ & $(0.280)$ \\
\hline \multirow{2}{*}{ Pre_subsidy } & $-1.116^{\star * *}$ & 0.362 \\
\hline & $(0.233)$ & $(0.559)$ \\
\hline \multirow{2}{*}{ Hi_edu } & 0.544 & 0.291 \\
\hline & $(0.398)$ & $(0.624)$ \\
\hline \multirow{2}{*}{ RD_int } & 0.148 & -0.056 \\
\hline & $(0.497)$ & $(0.641)$ \\
\hline \multirow{2}{*}{ Cap_int } & $-10.991^{\star * *}$ & -4.892 \\
\hline & $(2.431)$ & $(4.557)$ \\
\hline \multirow{2}{*}{ RD_Dpart } & $0.423^{* * *}$ & -0.188 \\
\hline & $(0.146)$ & $(0.255)$ \\
\hline \multirow{2}{*}{ Firm_Size } & $-0.940^{\star * *}$ & -0.270 \\
\hline & $(0.153)$ & $(0.314)$ \\
\hline \multirow{2}{*}{ _cons } & $4.056^{\star * *}$ & 1.870 \\
\hline & $(0.945)$ & $(1.885)$ \\
\hline $\mathrm{N}$ & 1274 & 280 \\
\hline Firm & 1274 & 280 \\
\hline Log likelihood & -401.168 & -194.066 \\
\hline Prob > chi 2 & 0.0000 & 0.9026 \\
\hline Pseudo $\mathrm{R}^{2}$ & 0.100 & 0.007 \\
\hline
\end{tabular}

Note: 1) Standard errors in parentheses; 2$)^{*} \mathrm{p}<0.1,{ }^{* *} \mathrm{p}<0.05$, $\left.{ }^{* *} \mathrm{p}<0.01 ; 3\right)$ All models include a set of industrial, and regional dummies (not reported); 4) Two firms receiving subsidies are dropped during the PSM process as they cannot satisfy the common support condition.

Table A.4. Balance test for the First-Step PSM

\begin{tabular}{|l|c|c|c|c|c|c|}
\hline & \multicolumn{2}{|c|}{ Means } & \multicolumn{2}{c|}{$\mathrm{t}$-test } & \multicolumn{2}{c|}{ MSB (\%) } \\
\hline Covariates & Treated & Control & $\mathrm{t}$ & $\mathrm{p}>\mathrm{t}$ & Before Match & After Match \\
\hline Tech_Capa & 0.220 & 0.228 & -0.22 & 0.825 & 13.3 & -2.7 \\
\hline Pre_subsidy & 0.028 & 0.014 & 0.82 & 0.411 & -44.5 & 5.1 \\
\hline Hi_edu & 0.142 & 0.136 & 0.42 & 0.678 & 10.1 & 4.9 \\
\hline RD_int & 0.076 & 0.079 & -0.19 & 0.847 & 8.9 & -2.8 \\
\hline Cap_int & 0.069 & 0.071 & -0.53 & 0.599 & 9.6 & -5.3 \\
\hline RD_Dpart & 0.887 & 0.915 & -0.79 & 0.428 & 19.8 & -8.0 \\
\hline Firm_Size & 5.100 & 5.096 & 0.06 & 0.956 & -39.6 & 0.5 \\
\hline
\end{tabular}




\section{A.2. Industrial and Regional distributions based on PSM samples}

Table A.5. Industrial distributions based on the PSM samples

\begin{tabular}{|c|l|c|c|c|}
\hline Code & \multicolumn{1}{|c|}{ Name } & Amount & $\begin{array}{c}\text { Subsidized } \\
\text { loans }\end{array}$ & $\begin{array}{c}\text { Only direct } \\
\text { grants }\end{array}$ \\
\hline 17 & Textile Industry & 8 & 0 & 4 \\
\hline 26 & $\begin{array}{l}\text { Raw Chemical Materials and Chemical } \\
\text { Products }\end{array}$ & 42 & 2 & 19 \\
\hline 27 & Medical and Pharmaceutical Products & 8 & 3 & 1 \\
\hline 28 & Chemical Fiber & 6 & 0 & 3 \\
\hline 29 & Rubber \& Plastic Products & 8 & 1 & 3 \\
\hline 30 & Nonmetal Mineral Products & 10 & 3 & 2 \\
\hline 31 & Smelting and Pressing of Ferrous Metals & 2 & 1 & 0 \\
\hline 32 & Smelting and Pressing of Nonferrous Metals & 2 & 1 & 0 \\
\hline 33 & Metal Products & 12 & 2 & 4 \\
\hline 34 & General Purpose Machinery & 12 & 2 & 4 \\
\hline 35 & Special Purposes Equipment & 66 & 9 & 24 \\
\hline 37 & Other Transport Equipment & 18 & 2 & 7 \\
\hline 38 & Electrical Machinery and Equipment & 22 & 4 & 7 \\
\hline 39 & $\begin{array}{l}\text { Computers, Communication, Other } \\
\text { Electronic Equipment }\end{array}$ & 32 & 4 & 12 \\
\hline 40 & Measuring Instruments and Machinery & 24 & 6 & 6 \\
\hline 41 & Other Manufacturing & 8 & 1 & 3 \\
\hline & Total & 280 & 41 & 99 \\
\hline & & & & \\
\hline
\end{tabular}

Table A.6. Area distributions based on the PSM samples

\begin{tabular}{|l|l|c|}
\hline \multicolumn{1}{|c|}{ Regions } & \multicolumn{1}{|c|}{ Cities } & Firm number \\
\hline The north region of Jiangsu (Su' Bei) & $\begin{array}{l}\text { Xuzhou, Lianyungang, Huai'an, } \\
\text { Yancheng, Suqian }\end{array}$ & 19 \\
\hline The central region of Jiangsu (Su' Zhong) & Yangzhou, Taizhou, Nantong & 43 \\
\hline The south region of Jiangsu (Su'Nan) & $\begin{array}{l}\text { Nanjing, Suzhou, Wuxi, Changzhou, } \\
\text { Zhenjiang }\end{array}$ & 218 \\
\hline Total & & 280 \\
\hline
\end{tabular}

